\title{
Mastektomi radikal pada kucing domestik di Klinik Hewan Pet Love Center
}

\author{
Ana Rufaidah $^{1, *}$, Arief Purwo Mihardi ${ }^{2}$, Didi Riyanto ${ }^{3}$ \\ ${ }^{1}$ Mahasiswa Program Pendidikan Profesi Dokter Hewan, Fakultas Kedokteran Hewan, IPB University, Bogor \\ ${ }^{2}$ Departemen Klinik Reproduksi dan Patologi, Fakultas Kedokteran Hewan, IPB University, Bogor \\ ${ }^{3}$ Dokter Hewan Praktisi Hewan Kecil di Klinik Hewan Pet Love Center, Jakarta Selatan
}

\begin{abstract}
ABSTRAK: Seekor kucing betina ras domestic shorthair yang berusia 15 tahun mengalami perbesaran dibagian mammae bagian kanan dan kiri yang sudah berlangsung kronis. Keadaan salah satu kelenjar mammae yang membesar pecah sehingga terjadinya pengeluaran discharge saat dibawa ke Klinik Hewan Pet Love Center. Dokter hewan melakukan pemeriksaan fisik dan pemeriksaan penunjang berupa hematologi, biokimiawi darah, dan x-ray sebelum operasi. Tindakan mastektomi radikal didukung dengan proses transfusi darah selama operasi berlangsung. Pengobatan pasca operasi diberikan injeksi dipenhydramine dan dexamethasone selama 3 hari, antibiotik, Hematodine dan Biodin selama 5 hari. Kondisi kucing setelah operasi dapat dikatakan cukup baik karena sudah makan dan minum. Luka jahitan terlihat sudah mulai mengering pada hari ke-3 pasca operasi.
\end{abstract}

\section{Kata Kunci:}

Kucing, domestic shorthair, mastektomi radikal, operasi, tumor mammae

\section{PENDAHULUAN}

Tumor mammae merupakan tumor yang umum terjadi pada kucing. Faktor risiko utama berkembangnya tumor mammae pada kucing yaitu termasuk pengaruh ras, usia, dan hormonal (Sorenmo 2011). Ras domestic shorthair dan Siamese memiliki tingkat kejadian lebih tinggi daripada ras lainnya. Kucing betina paling sering mengalami kasus tumor mammae dan jarang terjadi pada kucing jantan (OSU 2020).

Sekitar $85 \%$ tumor mammae kucing adalah ganas, dan secara histologis diklasifikasikan sebagai adenokarsinoma. Pengobatan dapat secara bedah, kemoterapi, terapi radiasi, dan imunoterapi, dan maupun kombinasi. Namun tumor ini cenderung kambuh atau berkembang di tempat baru dan menjadi penyebab kematian (Gemignani et al. 2018).

Pengobatan yang umum digunakan adalah melalui tindakan pembedahan, baik digunakan sendiri atau dalam kombinasi dengan kemoterapi. Mastektomi radikal yaitu pengangkatan semua kelenjar di sisi yang terkena adalah metode bedah pilihan karena secara signifikan mengurangi kemungkinan terjadinya kekambuhan tumor secara lokal. Tulisan ini melaporkan penanganan tumor mammae pada kucing domestik.

\section{- KASUS}

Anamnesis dan sinyalemen: Kucing betina ras domestic shorthair yang belum disteril bernama Bella berusia 15 tahun mengalami pembesaran pada kedua bagian rantai kelenjar mammari yang sudah berlangsung kronis (Gambar 1A). Bobot badan $3,8 \mathrm{~kg}$, suhu tubuhnya $38,7^{\circ} \mathrm{C}$ dan warna membran mukosa rose.
Pemeriksaan fisik: Massa yang tumbuh saat dipalpasi sudah mengeras dan tidak mudah untuk digerakkan. Temuan klinis: Salah satu bagian kelenjar mammae yang membesar pecah sehingga terjadi pengeluaran discharge. Pemeriksaan lanjut: X-ray dengan standar pandang ventrodorsal dan lateral recumbency menunjukan tidak terdapat pertautan massa dengan tulang maupun organ lainnya (Gambar 2). Hematologi lengkap menunjukan kadar RBC yang rendah (Tabel 1). Diferensial diagnosis: Tumor growth and abscess. Diagnosis: Tumor kelenjar mammae

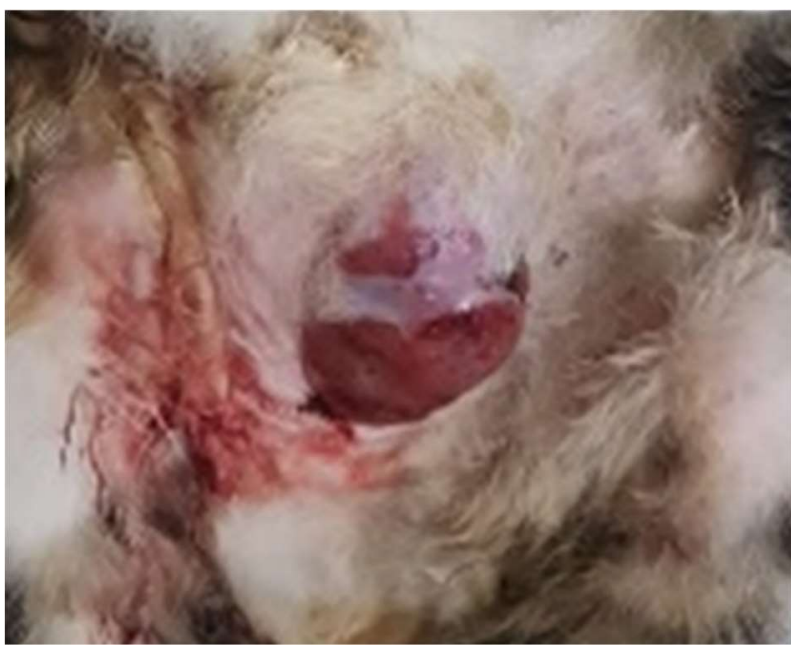

Gambar 1 kondisi kucing Bella dengan pembesaran pada kedua rantai kelenjar mammae yang sudah berlangsung kronis.

Diterima: 24-12-2020 | Direvisi: 20-01-2021 | Disetujui: 27-01-2021 (C) 2021 CC-BY-SA. Ini adalah artikel Open Access yang didistribusikan berdasarkan ketentuan dari Creative Commons Attribution ShareAlike 4.0 International License (https://creativecommons.org/licenses/by-sa/4.0/). 


\section{n HASIL DAN PEMBAHASAN}

Kasus tumor mammae pada kucing berumur tua dan belum disteril cenderung lebih banyak terjadi dibandingkan kucing muda dan sudah disteril (Memon et al. 2016). Pemeriksaan darah dilakukan untuk mengidentifikasi adanya kelainan prabedah. Radiografi torakoabdominalis ditujukan untuk menilai metastasis tumor ke bagian organ lain (khususnya paru-paru) maupun perlekatan dengan tulang. Tindakan bedah yang direkomendasikan adalah mastektomi radilkal.

Hasil pemeriksaan darah kucing Bella menunjukan rendahnya kadar RBC yang menandakan adanya anemia (Tabel 1). Transfusi darah perlu dilakukan selama operasi. Pencocokan silang adalah tes tambahan yang dilakukan sebelum transfusi darah. Sebelum transfusi, darah donor juga harus diskrining untuk mengetahui adanya penyakit menular.
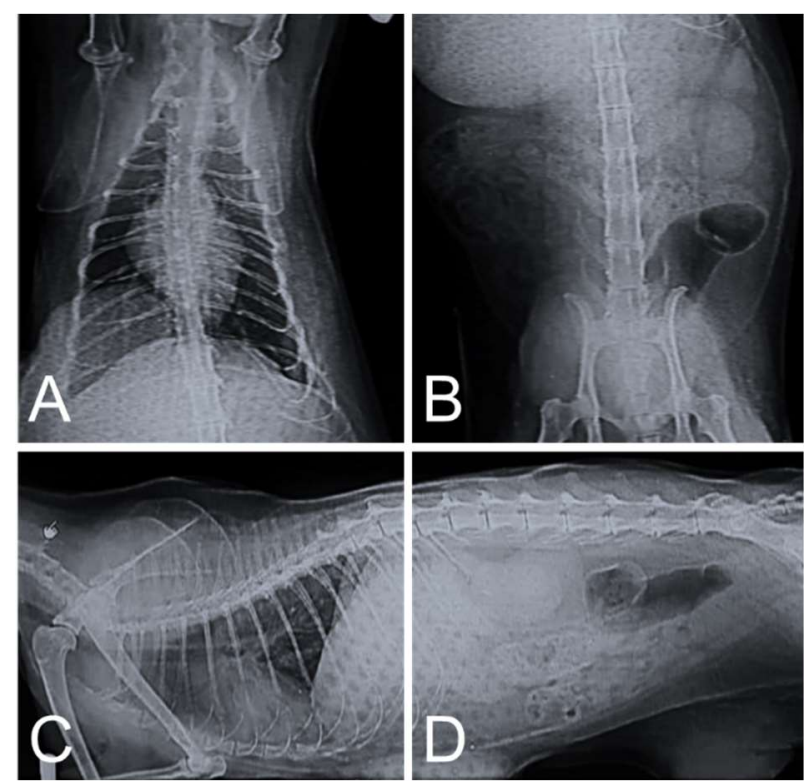

Gambar 2 Radiogram torakoabdominal kucing Bella pada sudut pandang ventrodorsal $(\mathrm{A}, \mathrm{B})$ dan lateral recumbency $(\mathrm{C}, \mathrm{D})$.

Prosedur mastektomi radikal dengan mengambil keempat kelenjar mammae, limfonodus axilla dan limfonodus inguinal untuk mengurangi resiko tumor kambuh (VHUP 2001). Namun dalam kasus kucing Bella hanya dilakukan pengangkatan limfonodus axilla karena pada limfonodus inguinalis tidak ada perubahan bentuk dan ukuran.

Tabel 1. Profil hematologi kucing Bella sebelum operasi

\begin{tabular}{lccc}
\hline \multicolumn{1}{c}{ Parameter } & Satuan & Sebelum Operasi & Range Normal \\
\hline WBC & $10^{9} / \mathrm{L}$ & 10,66 & $5,5-19,5$ \\
Limfosit & $10^{9} / \mathrm{L}$ & 2,37 & $1,5-7,0$ \\
Monosit & $10^{9} / \mathrm{L}$ & 0,99 & $0,0-1,5$ \\
Neutrofil & $10^{9} / \mathrm{L}$ & 15,14 & $2,5-1,4$ \\
Eosinofil & $10^{9} / \mathrm{L}$ & 0,16 & $0,0-1,0$ \\
Basofil & $10^{9} / \mathrm{L}$ & 0,01 & $0,0-0,2$ \\
RBC & $10^{12} / \mathrm{L}$ & 4,31 & $5,0-10,0$ \\
$\mathrm{Hb}$ & $\mathrm{g} / \mathrm{dL}$ & 6,40 & $8,0-15,0$ \\
$\mathrm{HCT}$ & $\%$ & 18,75 & $24,0-45,0$ \\
$\mathrm{MCV}$ & $\mathrm{fl}$ & 43,00 & $39,0-55,0$ \\
MCH & $\mathrm{pg}$ & 14,90 & $12,5-17,5$ \\
MCHC & $\mathrm{g} / \mathrm{dL}$ & 34,40 & $30,0-36,0$ \\
PLT & $10^{9} / \mathrm{L}$ & 194,00 & $300,0-800,0$ \\
\hline
\end{tabular}

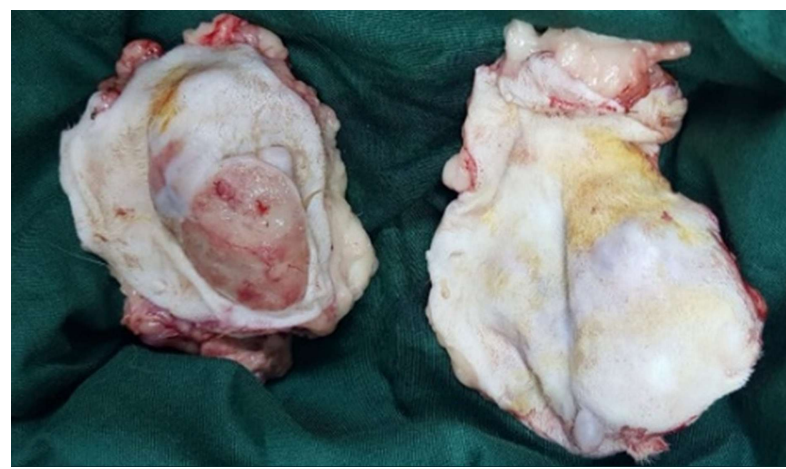

Gambar 2 Tumor mammae dari tubuh kucing Bella yang diangkat dengan tindakan mastektomi radikal.

Perawatan post operasi diberikan injeksi dipenhydramine $0,38 \mathrm{ml}$ IM dan dexamethasone $0,76 \mathrm{ml}$ IM $2 \times 1$ selama 3 hari untuk mencegah reaksi alergi dan peradangan pascatransfusi darah. Antibiotik Ceftriaxone $0,8 \mathrm{ml} \mathrm{IV}$, Hematodine $0,75 \mathrm{ml}$ $\mathrm{IM}$, dan Biodin 0,75 $\mathrm{ml} \mathrm{IM}$ diberikan 1x1 selama 5 hari. Kondisi kucing Bella setelah bangun dari pembiusan bisa dikatakan cukup baik karena sudah mau makan dan minum. Luka jahitan sudah mulai mengering di hari ke-3 pasca operasi, pergantian kassa dan perban dilakukan setiap hari.

\section{- SIMPULAN}

Mastektomi radikal merupakan tindakan yang efektif dalam menangani kasus tumor mammae pada kucing. Tindakan ini dapat meningkatkan masa kelangsungan hidup kucing dan mencegah terjadinya kekambuhan pertumbuhan tumor.

\section{- INFORMASI PENULIS}

Penulis untuk Korespondensi

*AR: ananasheer97@gmail.com

Mahasiswa Program Pendidikan Profesi Dokter Hewan (PPDH) Periode 2 Tahun 2019/2020, Fakultas Kedokteran Hewan, IPB, Jalan Agatis Kampus IPB Dramaga, Bogor, Jawa Barat, Indonesia

\section{- UCAPAN TERIMA KASIH}

Staf dokter hewan di Klinik Hewan Pet Love Center Jakarta Selatan.

\section{- PUSTAKA ACUAN}

[OSU] The Ohio State University. 2020. Feline Mammary Tumors. [Internet di akses 10/10/2020]. Tersedia pada: https://vet.osu.edu/vmc/companion/our-services/oncology-and-hematology/common-tumor-types/feline-mammary-tumors

[VHUP] Veterinary Hospital of The University Pennsylvania. 2001. Feline Mammary Tumors [Internet di akses 13/10/2020]. Tersedia pada: https://www.oncolink.org/cancers/vet/common-veterinarycancers/feline-mammary-tumors

Gemignani F, Mayhew PD, Giuffrida MA, Palaigos J, Runge JJ, Holt DE, Robertson NA, Seguin B, Walker M, Singh A, Liptak JM. 2018. Association of surgical approach with complication rate, progressionfree survival time, and disease-specific survival time in cats with mammary adenocarcinoma: 107 cases (1991-2014). Journal of the American Veterinary Medical Association. 252(11):1393-402.

Memon MA, Abbasi A, Abbasi IH, Mughal GA, Soomro RN, Memon AS. 2016. Surgical approaches to cat breast cancer (Mammary tumor), their treatment and management at Richmond Crawford Veterinary Hospital Karachi (RCVH), Sindh, Pakistan. ARC Journal of Animal and Veterinary Sciences (AJAVS). 2(1):23-28.

Sorenmo KU. 2011. Mammary Gland Tumors in Cats: Risk Factors, Clinical Presentation, Treatments and Outcome [Prosiding]. Philadelphia (USA): Veterinary Hospital of The University of Pennsylvania 